\title{
Urologia

\section{Fournier's Gangrene: Etiology and Outcome Analysis of 41 Patients}

\author{
Silvio Altarac ${ }^{a}$ Davorin Katušin ${ }^{b}$ Suad Crnica ${ }^{c}$ Dino Papeša ${ }^{a}$ Zoran Rajkovića $^{a}$ \\ Nuhi Arslanid \\ aDepartment of Surgery and Urology, Zabok General Hospital, Zabok, and Departments of b Urology and \\ 'Surgery, Karlovac General Hospital, Karlovac, Croatia; d Surgery Clinic, University Clinical Center Maribor, \\ Maribor, Slovenia
}

\section{Key Words}

Fournier's gangrene $\cdot$ Necrotizing fasciitis $\cdot$ Mortality $\cdot$ Severity of illness index

\begin{abstract}
Introduction: Fournier's gangrene $(\mathrm{FG})$ is the necrotizing fasciitis of the perineum and genital area with high mortality. Materials and Methods: A retrospective review included 41 patients diagnosed with FG in our hospitals from 1995 to 2010, divided into survivors and nonsurvivors. We analyzed anamnestic, clinical and laboratory data. Results: The mortality rate was $36.6 \%$ (15/41 patients). Elevated heart and respiratory rates, high serum creatinine, low serum bicarbonate, pre-existing kidney disease, and higher median extent of affected body surface were associated with higher mortality. Severe sepsis on admission and hypotension below $90 \mathrm{~mm} \mathrm{Hg}$ were also predictive for higher mortality. The median FG severity index (FGSI) score was higher in nonsurvivors (11 compared to $6, p<0.0001$ ). No cases of testicular necrosis were noted. Conclusion: Besides standard clinical and laboratory parameters included in the FGSI calculation, higher extent of affected body surface area and presence of hypotension on admission were also positively associated with mortality.

Copyright ๑ 2012 S. Karger AG, Basel
\end{abstract}

\section{Introduction}

Fournier's gangrene (FG) is the necrotizing fasciitis of the perineum and genital area with possible affection of the abdominal wall. It was named by the French dermatologist Jean-Alfred Fournier. He described fulminant gangrene of the penis and scrotum in five young men in 1883 [1]. Histopathologic examination of the affected skin and subcutaneous tissue shows cell necrosis, thrombosis of small vessels, infiltration with bacteria and inflammatory cells, and occasionally free air [2]. The cause of FG is mostly polymicrobial aerobic and anaerobic synergistic infection originating from a colorectal, genitourinary or skin infection site [3]. Although the disease is rare and accounts for $0.02 \%$ of all admissions to urology wards, it usually occurs in patients who are immunosuppressed due to comorbidities and who develop a primary infection site such as an abscess $[2,4]$. Despite a multidisciplinary approach that includes broad-spectrum antibiotics, radical surgical debridement and hemodynamic support in an intensive treatment unit, mortality rates are still very high [5]. The mortality rates are between 20 and $40 \%$ in most reports, but vary greatly and range from 4 to $88 \%$ [4].

\section{KARGER}

Fax +41613061234

E-Mail karger@karger.ch

www.karger.com
(C) 2012 S. Karger AG, Basel

$0042-1138 / 12 / 0883-0289 \$ 38.00 / 0$

Accessible online at:

www.karger.com/uin
Dino Papeš, MD

Department of Surgery and Urology, Zabok General Hospital

Bračak 8

HR-49210 Zabok (Croatia)

Tel. +385981620 627, E-Mail dinopapes@gmail.com 
Table 1. Analysis of age and predisposing factors

\begin{tabular}{lccl}
\hline & $\begin{array}{l}\text { Survivors } \\
(\mathrm{n}=26)\end{array}$ & $\begin{array}{l}\text { Nonsurvivors } \\
(\mathrm{n}=15)\end{array}$ & $\mathrm{p}$ \\
\hline Age, median (95\% CI) & $58(47,66)$ & $69(45,78)$ & 0.12 \\
Heart disease & $6(23.1)$ & $5(33.3)$ & 0.73 \\
Lung disease & $6(23.1)$ & $6(40.0)$ & 0.43 \\
Liver disease & $5(19.2)$ & $6(40.0)$ & 0.28 \\
Kidney disease & $2(7.7)$ & $8(53.3)$ & 0.0038 \\
Peripheral arterial disease & $6(23.1)$ & $8(53.3)$ & 0.10 \\
Diabetes & $7(26.9)$ & $6(40.0)$ & 0.60 \\
Hypertension & $16(61.5)$ & $10(66.6)$ & 0.99 \\
Malignant disease & $4(15.4)$ & $3(20.0)$ & 0.96 \\
$>1$ predisposing factor & $22(84.6)$ & $15(100.0)$ & 0.29 \\
Severe sepsis on admission & $6(23.1)$ & $11(73.3)$ & 0.0049 \\
Septic shock on admission & $0(0.0)$ & $2(13.3)$ & 0.25 \\
\hline
\end{tabular}

Figures in parentheses are percentages unless indicated otherwise.

Table 2. Analysis of infection sources

\begin{tabular}{llll}
\hline & $\begin{array}{l}\text { Survivors } \\
(\mathrm{n}=26)\end{array}$ & $\begin{array}{l}\text { Nonsurvivors } \\
(\mathrm{n}=15)\end{array}$ & $\mathrm{p}$ \\
\hline Colorectal & $15(57.7)$ & $8(53.4)$ & 0.95 \\
Abscess/infection & 11 & 4 & \\
Malignant disease & 4 & 4 & \\
Genitourinary & $7(26.9)$ & $2(13.3)$ & 0.53 \\
Abscess/infection & 6 & 1 & \\
Malignant disease & 1 & 1 & \\
Skin & $4(15.4)$ & $3(20.0)$ & 0.96 \\
Trauma & 2 & 1 & \\
Postoperative & 2 & 0 & \\
Pressure ulcer & 0 & 2 & 0.25 \\
Unknown source & $0(0.0)$ & $2(13.3)$ & \\
\hline
\end{tabular}

Figures in parentheses are percentages.

The objective of this study was to analyze clinical and laboratory parameters in patients with FG, and to report factors that determine, influence or predict mortality.

\section{Methods}

We conducted a retrospective study of all patients diagnosed with FG in our hospitals from 2000 to 2010. Patient data was obtained by searching the electronic medical record database. A total of 41 patients were found, and they were divided into two groups: survivors and nonsurvivors. The diagnosis of FG was established based on presenting history and clinical examination.
Collected data included: age, sex, risk factors, etiology, clinical signs and symptoms, clinical parameters (heart rate, temperature, respiratory rate), laboratory findings (serum sodium, potassium, creatinine and bicarbonate, and hematocrit and leukocyte count), duration of symptoms before admission, total extent of affected body surface, and number of surgical debridements.

The extent of involvement, total body surface area, was calculated using nomograms routinely used to assess the extent of burn injuries. The penis, scrotum and perineum each account for $1 \%$ surface area, and each ischiorectal fossa accounts for $2.5 \%$. For assessment of FG severity on admission, we used the FG severity index (FGSI) score, introduced by Laor et al. [6] in 1995, and presence of sepsis, severe sepsis or septic shock on admission. We calculated FGSI from clinical (temperature, heart and respiratory rate) and laboratory parameters (serum sodium, potassium, creatinine and bicarbonate, and hematocrit and leukocyte count) obtained on admission, as suggested by Laor et al. [6]: each parameter is given $0-4$ points, and FGSI is calculated by summing the points of each parameter. The cutoff point is 9 so that when FGSI is $>9$, the probability of death is $75 \%$, and when it is $\leq 9$, the probability of survival is $78 \%$.

Sepsis is defined as infection with systemic inflammatory response syndrome, which is manifested with two or more of the following findings: body temperature $<36^{\circ} \mathrm{C}\left(97^{\circ} \mathrm{F}\right)$ or $>38^{\circ} \mathrm{C}$ $\left(100^{\circ} \mathrm{F}\right)$, heart rate $>90$ beats $/ \mathrm{min}$, respiratory rate $>20$ breaths/ min or, on blood gas, a $\mathrm{PaCO}_{2}<32 \mathrm{~mm} \mathrm{Hg}(4.3 \mathrm{kPa})$, and leukocyte count $<4,000$ cells $/ \mathrm{mm}^{3}$ or $>12,000$ cells $/ \mathrm{mm}^{3}$, or $>10 \%$ immature forms. Severe sepsis is defined as sepsis combined with organ dysfunction, hypoperfusion or hypotension. Septic shock is defined as sepsis with refractory arterial hypotension or signs of systemic hypoperfusion in spite of fluid resuscitation $[7,8]$.

Statistical analysis was performed with MedCalc statistical software version 10.3 (copyrighted by MedCalc Software bvba) using a Mann-Whitney test, Fischer's exact test, and $\chi^{2}$ test, where applicable. $\mathrm{p}<0.05$ was considered statistically significant.

\section{Results}

Of 41 patients, 39 were male, and 2 female, both of whom were in the survivor group. The median age of all patients was 59 years (95\% CI: 51, 69; range: 33, 90). Patients were treated by repeated surgical debridements and broad-spectrum antibiotic therapy in the intensive treatment unit, and all were operated on within $24 \mathrm{~h}$ of admission. The mortality rate was $36.6 \%$ (15/41 patients). Age and predisposing factor analysis is shown in table 1 . Severe sepsis or septic shock on admission was noted in 13 of $15(86.7 \%)$ patients who died and in 6 of $26(23.1 \%)$ patients who survived, and the difference was significant $(\mathrm{p}=0.001)$. Analysis of the infection source is shown in table 2. Laboratory parameters analysis and analysis of FGSI, number of operations, skin surface affection and duration of symptoms before admission is shown in table 3. FGSI $>9$ was noted in 13 patients and FGSI $<9$ in 28 patients. The mortality rate was $84.6 \%$ in the group of 
Table 3. Analysis of laboratory parameters and analysis of FGSI, duration of symptoms before admission, number of operations, and skin surface affection

\begin{tabular}{|c|c|c|c|}
\hline Temperature, ${ }^{\circ} \mathrm{C}$ & $37.6(37.0,38.3)$ & $38.8(36.7,39.5)$ & 0.19 \\
\hline Pulse, bpm & $86(80,100)$ & $112(85,128)$ & 0.0411 \\
\hline Respiratory rate, $\mathrm{rpm}$ & $19(17,22)$ & $22(20,28)$ & 0.0074 \\
\hline Leukocyte count, $\times 1,000 / \mathrm{mm}^{3}$ & $15.5(10.8,18.0)$ & $18.0(9.9,20.0)$ & 0.29 \\
\hline Serum potassium, mmol/l & $4.0(3.4,5.0)$ & $4.2(3.8,5.5)$ & 0.08 \\
\hline Serum creatinine, $\mathrm{mmol} / \mathrm{l}$ & $138(88,173)$ & $280(130,430)$ & 0.0035 \\
\hline Serum bicarbonate, $\mathrm{mmol} / \mathrm{l}$ & $22.3(18.4,25.0)$ & $18.0(13.5,19.5)$ & 0.0110 \\
\hline FGSI & $6(5,7)$ & $11(8,13)$ & 0.0001 \\
\hline Duration of symptoms before admission, days & $3(3,4)$ & $4(3,5)$ & 0.11 \\
\hline Number of operations & $2(2,3)$ & $3(2,3.5)$ & 0.09 \\
\hline
\end{tabular}

Figures are medians (95\% CI) unless indicated otherwise.

patients with FGSI $>9(11 / 13$ patients) and $14.3 \%$ in the group of patients with FGSI $<9$ (4/28), and the difference was significant $(\mathrm{p}=0.0001)$. Overall, 8 patients $(19.5 \%)$ required suprapubic cystostomy, and $6(14.6 \%)$ required diverting colostomy, but the difference among survivors and nonsurvivors was not significant. Microbiological cultures were done in 37 patients. A single microorganism was isolated in 6 patients $(16.2 \%)$, and multiple microorganisms were found in 31 patients (83.8\%). The most common organisms were Streptococcus ( $\mathrm{n}=11 ; 29.7 \%)$, Bacteroides ( $\mathrm{n}=10 ; 27.0 \%)$, Escherichia coli $(\mathrm{n}=7 ; 18.9 \%)$, Staphylococcus $(n=6 ; 16.2 \%)$, Proteus $(n=4 ; 10.8 \%)$, Clostridium $(\mathrm{n}=3 ; 8.1 \%)$ and Pseudomonas $(\mathrm{n}=2 ; 5.4 \%)$. There was no significant difference between survivors and nonsurvivors in type or number of isolated microorganisms.

\section{Discussion}

FG is an extremely severe condition that requires immediate treatment. Several reports have stated that tissue necrosis can progress as fast as $2 \mathrm{~cm} / \mathrm{h}[9,10]$. Age and sex of patients in our study were similar to other reports, with no significant difference between survivors and nonsurvivors. The mortality rate was $36.6 \%$, similar as in some previous reports $[4,6]$. Nevertheless, as already mentioned, mortality rates vary greatly among different re- ports, although the treatment applied is similar or the same.

We found that the presence of kidney disease was associated with higher mortality. Concerning laboratory and clinical findings, elevated heart and respiratory rates, high serum creatinine, and low serum bicarbonate were associated with higher mortality. In different reports, changes in serum levels of hematocrit, leukocyte count, blood urea nitrogen, creatinine, serum sodium, potassium, magnesium, calcium, serum albumin, lactate dehydrogenase and alkaline phosphatase have been reported to be predictive for higher mortality $[6,11-14]$. In addition, elevated levels of fibrinogen and FVIII, low protein $\mathrm{C}$, and positive lupus anticoagulant were found in over $90 \%$ of patients in one series [15], and one study suggested that female sex is related to higher mortality [16]. We found that severe sepsis on admission, with hypotension below $90 \mathrm{~mm} \mathrm{Hg}$, was also predictive for higher mortality. Wound cultures were mostly polymicrobial and contained common skin, urinary tract and colonic pathogens, which is similar as in other reports [17, 18]. Also, no difference in isolated microorganisms was confirmed between survivors and nonsurvivors.

No specific bacterial pathogen has been linked with a higher tendency to cause FG or as a cause of higher mortality. According to the source of FG, we found no difference between survivors and nonsurvivors (table 2). Perianal/perirectal, periurethral and scrotal abscesses are the 
most common sources of the infection in most reports, but any skin lesion including pressure ulcer or surgical wound can act as a starting point for this disease. In our series we noted 2 cases of postoperative FG, one after hernia repair and one after open hemorrhoidectomy. The median number of operative debridements was higher in nonsurvivors (3 compared to 2), but this was not predictive for mortality in our report. This result is consistent with several other reports $[6,14,19]$, although there are series in which the higher number of operative debridements negatively affected survival [13]. This is most likely due to the fact that patients who require more debridements have a greater extent of disease and therefore a worse prognosis.

Aggressive and early surgical intervention is still considered the most effective treatment for FG. We found that the median extent of affected body surface was significantly higher in nonsurvivors. Intuitively, this is expected and has been reported in several other series [11, $12,20]$; however, there are reports in which such an association was not confirmed [17]. Affection of abdominal and lower extremity skin, which is usually associated with higher extent of affected body surface, was positively associated with mortality in our series. The median duration of symptoms before admission was a day longer in nonsurvivors (4 days compared to 3), but this was not associated with higher mortality. One other study reported a similar finding [17], but a positive correlation between the longer duration of symptoms and higher mortality has also been reported [21].

In our series, we did not notice any cases of testicular necrosis, and there was no need for orchidectomy. Some authors reported occurrence of testicular gangrene, up to $20 \%$, but the cause of the necrosis is still not clear because the anatomy of fascial layers in the perineum should in theory prevent the spread of the infection to the testicular tissue or damage to its blood supply [22, 23]. Several possible causes of testicular gangrene have been proposed: either the primary cause of the FG was orchidoepididymitis [24] that resulted in testicular destruction, or the infection spread deep into or from the retroperitoneum and then to the testis [3]. Also, it is possible that hypercoagulation and disseminated intravascular coagulation, which can occur in sepsis, can lead to occlusion of the small vessels of the testes and corpora cavernosa [25].

We conclude that FG is a life-threatening form of necrotizing soft tissue infection with high mortality. Repeated and radical surgical debridement and intravenous broad-spectrum antibiotics are the mainstream therapy. Besides the standard clinical and laboratory parameters included in the FGSI calculation, a higher extent of affected body surface area and presence of severe sepsis with hypotension on admission are also linked with higher mortality. The influence of greater number and extent of operative debridements and longer duration of symptoms before admission on mortality still need to be clarified, with a review of published articles. Also, the cause and etiology of testicular necrosis in FG still needs to be studied and made clear. Detailed analysis of the FG etiology and source, and path in which the infection spreads should be done in patients that develop testicular necrosis during FG. This could include analysis of testicular and spermatic cord tissue.

\section{References}

1 Fournier JA: Gangrene foudroyante de la verge. Semin Med 1883;3:345-348.

2 Schaeffer AJ, Schaeffer EM: Infections of urinary tract; in Kavoussi LR, Novick AC, Partin AW, Peters CA, Wein AJ (eds): CampbellWalsh Urology. Philadelphia, Saunders Elsevier, 2007, pp 301-302.

-3 Eke N: Fournier's gangrene: a review of 1,726 cases. Br J Surg 2000;87:718-728.

-4 Sorensen MD, Krieger JN, Rivara FP, Broghammer JA, Klein MB, Mack CD, Wessells $\mathrm{H}$ : Fournier's gangrene: population based epidemiology and outcomes. J Urol 2009; 181:2120-2126.

5 Ecker K, Baars A, Topfler J, Frank J: Necrotizing fasciitis of the perineum and the abdominal wall-surgical approach. Eur J Trauma Emerg Surg 2008;34:219-228.
-6 Laor E, Palmer LS, Tolia BM, Reid RE, Winter HI: Outcome prediction in patients with Fournier's gangrene. J Urol 1995;154:89-92.

$\checkmark 7$ Bone RC, Balk RA, Cerra FB, Dellinger RP, Fein AM, Knaus WA, Schein RM, Sibbald WJ: Definitions for sepsis and organ failure and guidelines for the use of innovative therapies in sepsis. The ACCP/SCCM Consensus Conference Committee. American College of Chest Physicians/Society of Critical Care Medicine. Chest 1992;101:1644-1655.

-8 Abraham E, Singer M: Mechanisms of sepsis-induced organ dysfunction. Crit Care Med 2007;35:2408-2416.

$>9$ Villanueva-Sáenz E, Martínez HernándezMagro P, Valdés Ovalle M, Montes Vega J, Alvarez-Tostado FJF: Experience in management of Fournier's gangrene. Tech Coloproctol 2002;6:5-10.
10 Frezza EE, Atlas I: Minimal debridement in the treatment of Fournier's gangrene. Am Surg 1999;65:1031-1034.

- 11 Yeniyol CO, Suelozgen T, Arslan M, Ayder AR: Fournier's gangrene: experience with 25 patients and use of Fournier's gangrene severity index score. Urology 2004;64:218222

12 Tuncel A, Aydin O, Tekdogan U, Nalcacioglu V, Capar Y, Atan A: Fournier's gangrene: three years of experience with 20 patients and validity of the Fournier's Gangrene Severity Index Score. Eur Urol 2006;50:838843.

13 Chawla SN, Gallop C, Mydlo JH: Fournier's gangrene: an analysis of repeated surgical debridement. Eur Urol 2003;43:572-575. 
14 Erol B, Tuncel A, Hanci V, Tokgoz H, Yildiz A, Akduman B, Kargi E, Mungan A: Fournier's gangrene: overview of prognostic factors and definition of new prognostic parameter. Urology 2010;75:1193-1198.

15 Sahin H, Aflay U, Kilinç N, Bircan MK: Coagulation parameters in the patients with Fournier's Gangrene. Int Urol Nephrol 2005; 37:733-737.

16 Czymek R, Frank P, Limmer S, Schmidt A, Jungbluth T, Roblick U, Bürk C, Bruch HP, Kujath P: Fournier's gangrene: is the female gender a risk factor? Langenbecks Arch Surg 2010;395:173-180.

- 17 Corcoran AT, Smaldone MC, Gibbons EP, Walsh TJ, Davies BJ: Validation of the Fournier's gangrene severity index in a large contemporary series. J Urol 2008;180:944948.
18 Marín AG, Gil JM, Rodríguez AV, Rodríguez TS, Palacios JT, Oliver JL, Fuentes FT: Fournier's gangrene: analysis of prognostic variables in 34 patients. Eur J Trauma Emerg Surg 2011;37:141-145.

19 Palmer LS, Winter HI, Tolia BM, Reid RE, Laor E: The limited impact of involved surface area and surgical débridement on survival in Fournier's gangrene. Br J Urol 1995; 76:208-212.

20 Dahm P, Roland FH, Vaslef SN, Moon RE, Price DT, Georgiade GS, Vieweg J: Outcome analysis in patients with primary necrotizing fasciitis of the male genitalia. Urology 2000;56:31-35.

21 Korkut M, Içöz G, Dayangaç M, Akgün E, Yeniay L, Erdoğan O, Cal C: Outcome analysis in patients with Fournier's gangrene: report of 45 cases. Dis Colon Rectum 2003;46: 649-652.
22 Koukouras D, Kallidonis P, Panagopoulos C, Al-Aown A, Athanasopoulos A, Rigopoulos C, Fokaefs E, Stolzenburg JU, Perimenis P, Liatsikos E: Fournier's gangrene, a urologic and surgical emergency: presentation of a multi-institutional experience with 45 cases. Urol Int 2011;86:167-172.

23 Ayan F, Sunamak O, Paksoy SM, Polat SS, As A, Sakoglu N, Cetinkale O, Sirin F: Fournier's gangrene: a retrospective clinical study on forty-one patients. ANZ J Surg 2005;75: 1055-1058.

24 Smith GL, Bunker CB, Dinneen MD: Fournier's gangrene. Br J Urol 1998;81:347-355.

25 Campos JA, Martos JA, Gutiérrez del Pozo R, Carretero P: Synchronous caverno-spongious thrombosis and Fournier's gangrene. Arch Esp Urol 1990;43:423-426. 